\title{
Review of Sustainable Heat in the Glasgow Subway Tunnels
}

\author{
Hytiris $\mathbf{N}^{1 *}$, Ninikas $\mathrm{K}^{2}$, Aaen $\mathrm{B}^{1}$ and Emmanuel $\mathbf{R}^{1}$ \\ ${ }^{1}$ Department of Geotechnics and Environmental Geotechnology, Glasgow Caledonian University, UK \\ ${ }^{2}$ University of Thessaly, Greece
}

Submission: November 16, 2020; Published: December 07, 2020

*Corresponding author: Hytiris N, Department of Geotechnics and Environmental Geotechnology Glasgow Caledonian University, UK

\section{Introduction}

Glasgow Caledonian University (GCU) commenced April 2014 looking into the potential for heat energy recovery from the water present within the Glasgow's Subway tunnel system. Glasgow Subway is owned, operated and maintained by Strathclyde Partnership for Transport (SPT). The opportunity came about due to GCU's involvement in an academic project looking the potential for district heating systems being fed from energy recovered from water in mine workings in and around Glasgow City Centre. This was of interest to the Strathclyde Partnership Transport (SPT) owing the Glasgow Subway, currently manages and removes (via pumping) large volumes from water that ingresses into the tunnels on a daily basis $[1,2]$. The water ingress causes dampness, corrosion and defects making it a major contributor to ongoing expensive infrastructure maintenance. As well as trying to prevent the water from entering the tunnels (through tunnel repair works), SPT were keen to establish if there was a beneficial use for the water to counter balance the cost of its removal and the maintenance impacts to the surrounding infrastructure.

\section{Feasibility Study}

Early into the data capture stage it was established that water ingress varies throughout the system and in some areas there was little potential. As such, a common approach to energy recovery across the system would be a challenge. However, given the depth of the tunnels, the ambient air temperature was established to remain above $14^{\circ}$ through the year. As such, the use of air for heat recovery was then also included in the scope of the project. As data and analysis progressed, it became evident that the potential for heat recovery from the water and air resources within the Subway tunnels was significant and greater than the basic heating needs of the local Subway stations and land. However, exploitation trials to prove the scale of potential were infeasible within the timescales of the GCU-SPT project programme, as wide scale implementation trials, would require significant third party involvement and buy in, not to mention significant additional funding [3,4]. As such it was agreed to undertake a staged approach to proving the potential and the technology, such that the trials were contained within SPT land and sphere of influence and also to establish a 'quick hit' outcome for the project.

\section{Pilot Study}

The project therefore worked towards establishing two trial sites in Subway stations - one with a water source heat recovery system (water source heat pump - WSHP) and one with an air source heat recovery system (air source heat pump - ASHP) [5,6]. The sites selected were St Georges Cross station for the water system and Bridge Street station for the air system. The trial sites were installed in October2015 \& November 2015, followed by a period of commissioning and monitoring. At the St. Georges Cross Station for example, almost a quarter of the overall water flux, instead of being discharged to the local sewers, is being used through the heat pump resulting in a reduction in the current pumping system operational hours.

\section{Energy Savings}

For each $\mathrm{kW}$ that is spent as energy input, there is a heat energy output of $2.75 \mathrm{~kW}$. This means that the energy cost for this station has been reduced accordingly and also the carbon footprint has also been reduced from $0.47 \mathrm{~kg} / \mathrm{kW}$ to $0.14 \mathrm{~kg} / \mathrm{kW}$. The payback period for this heating system, taking under consideration the actual equipment and installation cost is expected to be 12 years. At the Bridge Street station, an air source heat pump (ASHP) has been positioned below the stairs at platform level. The air from the tunnels is being absorbed from the unit (ASHP). An air draft with stable temperature between 14 to 17 degrees Celsius feed the unit. The "compact heating system" has been positioned at the station's canteen room. This provides the station's hot water and also feed with hot water the four radiators (fan coil units). The ASHP is 
currently operating with higher air temperatures compared to a unit which is positioned in an outdoor environment. This means less energy input to reach the desired temperature of 45 degrees Celsius, therefore higher output. At the Bridge Street Station there is $3.6 \mathrm{~kW}$ heat output for every $1 \mathrm{~kW}$ energy input. This means that the energy cost for this station has been reduced accordingly and also the carbon footprint has also been reduced from $0.47 \mathrm{~kg} / \mathrm{kW}$ to $0.17 \mathrm{~kg} / \mathrm{kW}$. The payback period for the Bridge Street Station heating system, taking under consideration the actual equipment and installation cost is expected to be 9 years. Through this project a data base has been created with water readings for each sump for a period of 18 months. The maximum heat energy output using the water and the air in each station has been identified. Through the design and implementation of the two trial installations, one for water and for air, the energy input reduction for heating and domestic hot water has been proven. The carbon footprint has been reduced by $2 / 3$ at both trials. This project has engaged the SPT's Stakeholders showing them a smart use of their resources through an environmental friendly approach [7-12].

\section{Limitations}

There are some limitations, barriers and opportunities to extensively apply shallow geothermal heat harvesting to the whole Subway network and elsewhere. The continuity of water is one of them. Out of the fifteen stations, a heating system based on the water can be assumed only in few sites due to different water ingress at each location. This waste resource has not been fully exploited due to some constrains mentioned previously.

\section{Further Installations}

Meanwhile, the ASHP approach has driven the SPT to further roll out this heating system to 5 more stations within its network reducing the energy input with regard to the stations needs for heating and domestic hot water. The WSHP hasn't been implemented in other stations due to the minimum water presence in various Subway stations and also due to the complexity of the overall installation.

\section{Opportunities}

However, a number of implementations have to be acknowledged and developed to transform such opportunities into real applications and viable projects. The heat map is one, but not the only necessary tool. Other European companies operating underground metro systems with a similar setup (existence of wastewater in large quantities or warmed air) should proceed with specific steps through feasibility studies to identify key characteristics of the water and/or air within their systems with a view to commercialize this resource. A year round survey is necessary with regards to the following: quantity, quality and temperature of water. These three, are essential to assess the real potentials for heat recovery and afterwards to seek for customers to provide this secondary energy source. On the other hand, developers and businesses have to seek for new ways of exploiting available resources in close proximity to their properties based on key factors such as sustainability and waste resource management towards energy.

\section{Awards / Prizes}

Winner of SCOTTISH TRANSPORT AWARDS 2016 for contribution to Sustainable Transport Strathclyde Partnership for Transport -Ground Water and Air Source Heat System on the Subway. https://www.transporttimes.co.uk/news. $\mathrm{ph}$ /THE-SCOTTISH-TRANSPORT-AWARDS-2016-WINNERSANNOUNCED-130/.

\section{References}

1. Ninikas K, Hytiris N, Emmanuel R, Aaen B (2019) Recovery and valorisation of energy from wastewater using a water source heat pump at the Glasgow Subway. Potentials for similar Underground environments. Resources Journal (MDPI).

2. Ninikas K, Hytiris N, Emmanuel R, Aaen B (2019) The performance of an ASHP system using waste air to recover heat energy in a Subway system. Clean Technologies Journal (MDPI).

3. Ninikas K, Hytiris N, Emmanuel R, Aaen B (2017) Heat Energy Output from a Shallow Geothermal Open Loop System in Glasgow Performance Evaluation Design, Installation and Performance. Environmental Geotechnics Journal, Institution of Civil Engineers (ICE).

4. Ninikas K, Hytiris N, Emmanuel R, Aaen B, Younger PL (2016) Heat recovery from air in underground transport tunnels. Renewable Energy Journal, Elsevier.

5. Hytiris N, Ninikas K, Emmanuel R, Aaen B, Younger PL (2016) A heat energy recovery system from tunnel waste water. Environmental Geotechnics Journal, Institution of Civil Engineers (ICE).

6. Hytiris N, Emmanuel R, Aaen B, Church E, Campbell D, Ninikas K, Robertson A (2015) Heat Energy Recovery from Mineworkings. Opportunities in the Glasgow area. Environmental Geotechnics Journal, Institution of Civil Engineers (ICE). 
Your next submission with Juniper Publishers will reach you the below assets

- Quality Editorial service

- Swift Peer Review

- Reprints availability

- E-prints Service

- Manuscript Podcast for convenient understanding

- Global attainment for your research

- Manuscript accessibility in different formats

( Pdf, E-pub, Full Text, Audio)

- Unceasing customer service

Track the below URL for one-step submission https://juniperpublishers.com/online-submission.php 